Research Report No. 21/2013

\title{
Knowledge in Development, Law and Regulation, or How are We to Distinguish between the Economic and the Non-Economic?
}

Peer Zumbansen

Osgoode Hall Law School of York University, PZumbansen@osgoode.yorku.ca

Follow this and additional works at: http:// digitalcommons.osgoode.yorku.ca/clpe

\section{Recommended Citation}

Zumbansen, Peer, "Knowledge in Development, Law and Regulation, or How are We to Distinguish between the Economic and the Non-Economic?" (2013). Comparative Research in Law \& Political Economy. Research Paper No. 21/2013.

http://digitalcommons.osgoode.yorku.ca/clpe/268 


\section{OSGOODE}

OSGOODE HALL LAW SCHOOL YOR K U N I VERSITY

\section{OSGOODE HALL LAW SCHOOL}

Comparative Research in Law \& Political Economy

RESEARCH PAPER SERIES

Research Paper No. 21/2013

Knowledge in Development, Law and Regulation, or How are We To Distinguish Between the Economic and the Non-Economic?

Peer Zumbansen

\section{Editors:}

Peer Zumbansen (Osgoode Hall Law School, Toronto, Director Comparative Research in Law and Political Economy)

John W. Cioffi (University of California at Riverside)

Leeanne Footman (Osgoode Hall Law School, Toronto, Production Editor)

Comparative Research in Law \& Political Economy 


\title{
Knowledge in Development, Law and Regulation, or How are We To Distinguish Between the Economic and the Non-Economic?
}

\author{
Peer Zumbansen ${ }^{1}$ \\ Forthcoming in: Critical Legal Perspectives on Global Governance. Liber Amicorum David M. Trubek (Gráinne de \\ Búrca, Claire Kilpatrick \& Joanne Scott, Hart Publishing 2013)
}

\begin{abstract}
:
This chapter explores the nature, status and role of knowledge, expertise and epistemology in the context of law \& development. Placing a particular emphasis on the way that prior perceptions of the functions of the state influence the conceptualization of development policies, the chapter formulates a critique of approaches to development programs that export 'learned lessons' from state change and state transformation into development contexts without paying due regard to the differences in socio-economic and legal governance structures on the ground. The chapter argues against a number of existing positions with regard to the approach to be taken vis-à-vis legal and economic assistance in developing countries, including those that too simply assume a gap between 'modern' and 'traditional' conceptions of societal governance. Furthermore, the chapter critically engages with approaches that seek to import a particular, 'Western' conception of the rule of law to developing countries without taking into account the complex trajectory marking the evolution of political and legal governance from the colonial to post-colonial stage. Knowledge as a governance instrument becomes a crucial variable in this regard as it allows for a more adequate study of the way in which choices are made between different bodies of theories and information governing the development policy. The chapter furthermore juxtaposes law \& development with the increasingly important research and policy field of transitional justice in order to highlight the overlaps between both fields.
\end{abstract}

Keywords: Law \& development; rule of law; economic progress; modernity; knowledge; legal pluralism; transitional justice.

\section{Introduction}

On Sunday, 17 June 2012, while Germany commemorated the 1953 uprising in Berlin of workers and citizens protesting against the East German government, the citizens of Munich were called on to cast their votes in connection to the city's and its airport's proposal to build a third runway. With a 33 per cent participant turn-out, 54,3 per cent of Munich's voters rejected the expansion plans for the airport - against an approving 45,7 per cent. In political commentary the following morning, the triumphant voters, rallied around, inter alia, civic initiatives such as 'Plane Stupid Germany' and 'Aufgemuckt' (which might translate as 'up in

\footnotetext{
${ }^{1}$ I am grateful to Marta Jankovic, Hengameh Saberi, Sujith Xavier and to the participants of the conference Critical Legal Perspectives on Global Governance: Liber Amicorum David M Trubek, held at the European University Institute, 28-30 June 2012 for helpful feedback.

${ }^{2}$ www.airportwatch.org.uk/?p=2019.
} 
arms'), represented the results as a clear signal that people wanted to 'put an end to the growth mania' and economic exuberance. By contrast, the proponents of the airport extension, a conglomerate of mostly the conservative political parties and industry representatives, ${ }^{3}$ recognised that the decision against the runway communicated a lack of understanding for the importance of the expansion to foster economic growth and prosperity and future-oriented sustainability. ${ }^{4}$

And so, we might say, the story goes. And goes and goes and goes. While the sites and instances might change, the vocabularies remain the same, reflecting perhaps the predictability and polemics of politically opposed views. Seen that way, it would appear as if things have always been relatively simple, refreshingly black, or white: Interests, viewpoints and arguments can surely be demarcated along the distinction between economic and non-economic, as if such a distinction were in fact possible.

Yet, how does this observation relate to the discourses that we all find ourselves in these days - sometimes actively as contributors, at other times more passively as listeners, readers, or bystanders? Discourses around seemingly unruly, boundary-less, problematic concepts; concepts that resist containment and fail to synthesise issues. Consider concepts such as 'global governance', 'regulatory capitalism', 'global legal pluralism', 'global constitutionalism' and 'transitional justice'. Such discourses seem to be, above all, marked by an inquiring, conceptualising impulse, in that they open up vistas and raise questions about connections between different approaches, even as they too often disappoint (in being too 'modest'? ${ }^{5}$ ).

But, still we seem to endorse the intriguing nature of today's deliberations about the functions, the scope and the - fragmented ${ }^{6}$ - foundations of global governance instantiations, precisely because we are experiencing the cacophony of descriptive versus prescriptive, sociological versus normative, traditional versus innovative assertions as unavoidable. If we are to crystallise rules for the global governance definition game, then surely there is no way around an earnest engagement with both multi-disciplinarity and inter-disciplinarity. Increasingly aware, how global governance confronts us with a host of methodological questions, we are finding ourselves engaging with wide-ranging materials from a host of disciplines. Meanwhile, however, the question of method seems to beg another, possibly just as important one: What is at stake, really, in this labour-intensive investigation into the different layers of so-called 'global governance'? And, for whom? What lessons, if any, are we becoming able to draw from such efforts - in a more concrete, political way?

Through a dialogue with some of the themes introduced into the scholarship in L\&D and global governance by David Trubek, the present paper hopes to explore ways in which it might be possible and eventually rewarding to pick up on both of these challenges. The chosen

\footnotetext{
${ }^{3}$ See, for example, www.planestupid-germany.de/en/home-en/95-stop-the-third-runway-madness.html; www.ja-zur3.de/England, and www.munich-business-school.de/nc/en/experience-mbs/news/news-detailview/artikel/munichbusiness-school-tritt-dem-buendnis-zur-unterstuetzung-des-ausbaus-der-dritten-startbahn-amflug.html?tx_ttnews[backPid]=28\&cHash=2629b63e97.

${ }^{4}$ Bürgerentscheid in München: Startbahngegner stoppen Flughafenausbau' (Spiegel Online, German edition, 18 June 2012), available at www.spiegel.de/wirtschaft/soziales/flughafen-muenchen-startbahngegner-stoppen-wohlausbau-a-839408.html.

${ }^{5} \mathrm{~N}$ Krisch, 'Global Administrative Law and the Constitutional Ambition' in P Dobner and M Loughlin (eds), The Twilight of Constitutionalism? (Cambridge, Cambridge University Press, 2010), 245.

${ }^{6}$ G Teubner, 'Fragmented Foundations: Societal Constitutionalism beyond the Nation State' in P Dobner and M Loughlin (eds), The Twilight of Constitutionalism? (n 5), 327, and see now his monographic study, G Teubner, Verfassungsfragmente. Gesellschaftlicher Konstitutionalismus in der Globalisierung (Berlin, Suhrkamp, 2012).
} 
approach is a short-circuiting of a number of debates which have been and continue to be central elements in fast evolving global governance discourses. The goal behind this linking exercise is to lay bare continuities and legacies of certain, currently fashionable, approaches and concepts in global governance debates in order to show the degree to which we can see some of them to be re-instantiations, reformulations or, rediscoveries of concepts and terminologies which were introduced at a much earlier stage and which might seem 'dated' or simply of no obvious use in the context of today's debates. There seems to be little need to 'justify' such an endeavour. Historically and theoretically informed and insatiably curious scholarship bears the inspiring hallmark of both being 'right on the money' and ageing well. ${ }^{7}$ The next section will begin to explore the scope and boundaries of 'law and development' (L\&D) in relation to a fastintensifying discourse on 'transitional justice' (II) and then contextualise this analysis in a conception of 'spatial' governance (III). The concluding section will, subsequently, investigate the category of 'knowledge' as the crucial variable in the linking of domestic and transnational governance discourses (IV).

\section{Law \& Development and Transitional Justice as Global Governance Discourses}

Contributing to a Symposium around David Trubek's longstanding work in critical legal scholarship, law and development, new governance and legal theory inevitably prompts reflections on the trajectories, lessons and prospects of such an endeavour. In that respect, the oeuvre of such a scholar can fruitfully be seen as a time keeper, seismographic instrument and yardstick. Inspired by the arc drawn in his work from the critical self-reflection on development law in the 1970s to the scrutiny of different competing models of the 'state' in the present phase of law and development, I hope to offer a supportive and complementary account, which connects domestic governance discourses with global governance and global constitutionalism discourses in the context of the transnational regulatory landscape. By contrasting domestic accounts of the state's institutional and normative 'infrastructure' such as the Rule of Law, Due Process, Rights and constitutional hierarchy with the apparently fragmentary and deficient elements of an evolving global legal order, it might be possible to gain insights into the dynamics of 'development law' in the global context today. As domestic regulatory paradigms are being revisited, scrutinised, and tested as to their compatibility with and transferability to the global realm, we now, more than ever, have to recognise the connections and interdependencies between the understandings of 'our' and of 'foreign' law, or 'our' and 'foreign' models of the state, of 'their' and 'our' perceptions of law's role in society. In other words, reflecting on a legal theory of law and development and of global governance becomes an exercise in epistemology, an ascertaining of how 'we' and 'the other' have learned to conceive of regulatory challenges as legal ones, of competing models of the state, of democratic governance or economic regulation.

\footnotetext{
${ }^{7}$ See, eg, DM Trubek, 'Max Weber on Law and the Rise of Capitalism' (1972) Wisconsin Law Review 720; DM Trubek, 'Toward a Social Theory of Law: An Essay on the Study of Law and Development' (1972) 82 Yale Law Journal 1; DM Trubek, J Mosher and JS Rothstein, 'Transnationalism and the Regulation of Labor Relations: International Regimes and Transnational Advocacy Networks' (2000) Law and Social Inquiry 1187; DM Trubek and L Trubek, 'Hard and Soft Law in the Construction of Social Europe: the Role of the Open Method of Coordination' (2005) 11 European Law Journal 343.
} 
As such, this chapter engages with and comments on David Trubek's innovative scholarship on both law and development $\mathrm{L} \& \mathrm{D}^{8}$ and 'new governance'. 9 . First, I hope to underline the particular quality and character of an intellectual and political approach to the development of a critical legal research program that critically illuminates the context of legal debates and scrutinises the use of allegedly neutral legal categories (such as the rule of law, property, or the state) in a charged discursive universe. ${ }^{10}$ Secondly, I hope to be able to highlight the general significance of the field of 'law and development' L\&D for a better understanding of the relationship between legal and economic governance discourses, which informs this field perhaps more than any other. Lastly, by focusing on the concept of 'knowledge' as it has been employed by Trubek in his more recent work on the 'new developmental state', ${ }^{11}$ I want to draw connections between the assertions of the critical role of knowledge in development contexts on the one hand, and domestic governance contexts, on the other.

Law and Development, one of the fields where David Trubek's made some of his most important scholarly contributions, has always been an area which can neither be neatly and clearly defined nor boxed into clear-cut categories. The field has long been a battle field for opposing concepts of law, political and economic order and the role of institutional governance, ${ }^{12}$ and as such has always been a laboratory for audacious experiments with explosive material. Categories such as 'progress', 'development' or 'order' are invariably contentious, and in the context of L\&D are employed as bargaining chips in a high-stakes game over political and economic influence, autonomy and, emancipation. ${ }^{13}$ While specific local contexts of L\&D became the loci of such contestation, often enough under the magnifying glass of international and national development agendas, market integration and state reform, one of the most striking discoveries to be made here relates to the fact that the contentious items in the L\&D context are also those which have long informed a critical analysis of law and governance in the context of the nation state. ${ }^{14}$ As such, the boundaries between the developing and the developed world, between those countries receiving and those exporting or providing legal (or economic) aid become porous, and a legal theory of L\&D can fruitfully build on its older domestic sister.

Among the important scholarly projects pursued by L\&D scholars has been the discovery and analysis of the legal pluralist nature of the governance orders in the context of

\footnotetext{
${ }^{8}$ See, DM Trubek, 'Toward a Social Theory of Law: An Essay on the Study of Law and Development' (1972) 82 Yale Law Journal 1; DM Trubek and M Galanter, 'Scholars in Self-Estrangement: Some Reflections on the Crisis in Law and Development Studies in the United States' (1974) Wisconsin Law Review 1062; DM Trubek and A Santos, 'Introduction: The Third Moment in Law and Development Theory and the Emergence of a New Critical Practice' in DM Trubek and A Santos (eds), The New Law and Economic Development (Cambridge, Cambridge University Press, 2006), 1-18, and DM Trubek, 'Developmental States and the Legal Order: Towards a New Political Economy of Development and Law' (2008) University of Wisconsin Legal Studies Research Paper No. 1075.

${ }^{9}$ See, eg, DM Trubek and L Trubek, 'Hard and Soft Law in the Construction of Social Europe' (n 7).

${ }^{10}$ For a powerful illustration of such an approach, see Priya S. Gupta, 'The Peculiar Circumstances of Eminent Domain in India' (2012) 49:3 Osgoode Hall Law Journal 445, 453-456.

${ }^{11}$ See the overview at www.law.wisc.edu/gls/lands.html.

${ }^{12}$ D Kennedy, 'Laws and Development' in J Hatchard and A Perry-Kessaris (eds), Law and Development: Facing Complexity in the 21st Century - Essays in Honour of Peter Slinn (London, Cavendish Publishing Limited, 2003), 17.

${ }^{13}$ For a brilliant deconstruction of the post-war conceptual division between political and economic emancipation of former colonial states, see S Pahuja, Decolonising International Law: Development, Economic Growth and the Politics of Universality (Cambridge, Cambridge University Press, 2011).

${ }^{14}$ The masterful analysis is still DM Trubek and M Galanter, 'Scholars in Self-Estrangement' (n 8).
} 
development. ${ }^{15}$ With a growing awareness of the different, existing ordering structures 'on the ground' in the development context came the realisation that any legal order challenges the observer to acknowledge the parallels between and the co-existence of formal and informal, hard and soft law, of legal and non-legal norms. ${ }^{16}$ This realisation prompted L\&D scholars to acknowledge but also to build on the idea that many of the challenges pertaining to a law/nonlaw distinction that had been identified as specific to the development context, were in fact detachable from any legal governance framework. Indeed, the inadequacy of existing legal governance thinking pointed to the need for a different theoretical — but also, doctrinal attention. $^{17}$

It is this realisation that allows for a better appreciation of the questionable foundations of a legal 'order', of the embeddedness of legal governance in a particular institutional setting (eg, the 'state') and at a particular moment in (geo-political) time. ${ }^{18}$ To the degree that the struggle over law 'reform' in the context of development is seen as not entirely removed from contestations of legal (political, economic) order in the domestic context, L\&D emerges as a field, which is just as much concerned with the relationship of law to its (particular, local) social environment and context as that has been the case for any other legal theoretical or legal sociological inquiry. ${ }^{19}$ But, accepting this perspective also implies accepting the loss of an outside observer's standpoint. Precisely, by acknowledging the inseparability of critical legal analysis in the domestic and the 'development' context, we lose the comfort of being 'outside' of the sphere which we are purporting to study and to examine in a disinterested manner. ${ }^{20}$ Instead, the demarcation of the L\&D context from that of one's home legal system and jurisdiction becomes questionable in itself, because the assertions of law's precariousness in the development context apply to the domestic home context with equal force. On that basis, the distinction between governance challenges 'there' and 'here' appears artificial. Indeed, the distinction seems designed to insulate the domestic context from critique while depicting the development context as deficient and requiring 'aid' and assistance. The identification of a series of legal governance questions as arising from within the context of a 'developing country' inevitably leads to these questions having to be seen as already pertinent much 'earlier', namely already present and evident in the context of domestic legal critique.

\footnotetext{
${ }^{15}$ K Pistor and D Berkowitz, 'Of Legal Transplants, Legal Irritants, and Economic Development' in P Cornelius and B Kogut (eds), Corporate Governance and Capital Flows in a Global Economy (Oxford, Oxford University Press, 2003), 347; K Pistor, 'The Standardization of Law and Its Effect on Developing Economies' (2002) 50 American Journal of Comparative Law 97.

${ }^{16}$ HW Arthurs, Without the Law: Administrative Justice and Legal Pluralism in Nineteenth Century England (Toronto, University of Toronto Press, 1988); RA Macdonald and J MacLean, 'No Toilets in Park' (2005) 50 McGill Law Journal 721; SF Moore, 'Law and Social Change: The Semi-Autonomous Field as an Appropriate Subject of Study' (1973) 7 Law \& Society Review 719.

${ }^{17}$ Macdonald and MacLean, ibid. See also C Scott, 'A Core Curriculum for the Transnational Legal Education of JD and LLB Students: Surveying the Approach of the International, Comparative and Transnational Law Program at Osgoode Hall Law School' (2005) 23 Penn State International Law Review 757.

${ }^{18}$ Begoña Aretxaga, 'Maddening States' (2003) 32 Annual Review of Anthropology 393.

${ }^{19}$ R Cotterrell, 'Why Must Legal Ideas Be Interpreted Sociologically?' (1998) 25 Journal of Law \& Society 171; R Banakar, 'Law Through Sociology's Looking Glass: Conflict and Competition in Sociological Studies of Law' in A Denis and D Kalekin-Fishman (eds) The ISA Handbook in Contemporary Sociology (London, Sage Publications Ltd, 2009); P Zumbansen, 'Law's Effectiveness and Law's Knowledge: Reflections from Legal Sociology and Legal Theory' (2009) 10 German Law Journal 417.

${ }^{20}$ DM Trubek and M Galanter (n 8). See also DM Trubek, 'Toward a Social Theory of Law: An Essay on the Study of Law and Development' (1972) 82 Yale Law Journal 1.
} 
A striking feature of this contextualisation of L\&D as part of a larger exercise in investigating law's relationship to and role in society, is the way, in which the field opens itself up to an engagement and exchange with complementary discourses about regulatory places and spaces. Both legal scholars ${ }^{21}$ and sociologists ${ }^{22}$ have been scrutinising the conceptual and constituted nature of such regulatory spaces; spaces which escape a straight-forward depiction from a single discipline's vantage point. Just as this critique has become pertinent with regard to the analysis of different, specialised regulatory arenas, ranging from labour ${ }^{23}$ to corporate ${ }^{24}$ from environmental $^{25}$ to criminal law, ${ }^{26}$ altogether suggesting a methodological shift from comparative to transnational law, ${ }^{27} \mathrm{~L} \& \mathrm{D}$ has become a very active laboratory for a renewed engagement with a critical and contextual analysis of law in a fast-changing and volatile environment.

This aspect has been underlined, perhaps most tellingly, by the recent approximation of L\&D with the field of 'transitional justice', which testifies to an increasing awareness among interested experts of the close connections between investigations into the 'legacies' of past injustices with programs of future-directed legal and economic aid. ${ }^{28}$ Closely connected to and oftentimes overlapping with this very vivid scholarly engagement has, of course, been an equally

${ }^{21}$ R Ford, 'Law's Territory (A History of Jurisdiction)' (1999) 97 Michigan Law Review 843.

${ }^{22}$ S Sassen, 'The State and Globalization' in JS Nye and JD Donahue (eds), Governance in a Globalizing World (Washington, Brookings Institution, 2000), 91; S Sassen, 'The Places and Spaces of the Global: An Expanded Analytic Terrain' in D Held and A McGrew (eds), Globalization Theory. Approaches and Controversies (Cambridge, Polity, 2007), 79; D Harvey, 'The Sociological and Geographical Imaginations' (2005) International Journal of Politics, Culture and Society 211.

${ }^{23}$ DM Trubek, J Mosher and JS Rothstein, 'Transnationalism and the Regulation of Labor Relations' (n 7); G Mundlak, 'De-Territorializing Labor Law' (2009) 3 Law \& Ethics of Human Rights 188; HW Arthurs, 'Extraterritoriality by Other Means: How Labor Law Sneaks across Borders, Conquers Minds, and Controls Workplaces Abroad' (2010) 21 Stanford Law \& Policy Review 527.

${ }^{24}$ LC Backer, 'Private Actors and Public Governance Beyond the State: The Multinational Corporation, the Financial Stability Board, and the Global Governance Order' (2011) 18 Indiana Journal of Global Legal Studies 751; P Zumbansen, 'Neither "Public" nor "Private", "National" nor "International": Transnational Corporate Governance from a Legal Pluralist Perspective' (2011) 38 Journal of Law \& Society 50.

${ }^{25}$ L Gulbrandsen, S Andresen and JB Skjærseth, 'Non-State Actors and Environmental Governance: Comparing Multinational, Supranational and Transnational Rule Making' in B Reinalda (ed), The Ashgate Research Companion to Non-State Actors (Aldershot, Ashgate, 2011), 463; N Craik, 'Deliberation and Legitimacy in Transnational Environmental Governance’ (2006) IILJ Working Paper 2006/10, New York University, Global Administrative Law Series; C Kamphuis, 'Canadian Mining Companies and Domestic Law Reform: A Critical-Legal Account' (2012) 13 German Law Journal 1456; S Seck, 'Home State Regulation of Environmental Human Rights Harms As Transnational Private Regulatory Governance' (2012) 13 German Law Journal 1360.

${ }^{26}$ N Boister, 'Transnational Criminal Law?' (2003) 14 European Journal of International Law 953; N Boister, An Introduction to Transnational Criminal Law (Oxford, Oxford University Press, 2012); RJ Currie, International and Transnational Criminal Law (Toronto, Irwin Law, 2010).

${ }^{27}$ CM Scott, "'Transnational Law" as Proto-Concept: Three Conceptions' (2009) 10 German Law Journal 859; P Zumbansen, 'Transnational Legal Pluralism' (2010) 1 Transnational Legal Theory 141; P Zumbansen, 'Transnational Law, Evolving' in J Smits (ed) Elgar Encyclopedia of Comparative Law 2nd ed. (Cheltenham, Edward Elgar, 2012).

${ }^{28}$ See, eg, R Mani, 'Dilemmas of Expanding Transitional Justice, or Forging the Nexus between Transitional Justice and Development' (2008) 2 International Journal of Transitional Justice 253, and the contributions to P De Greiff and R Duthie (eds), Transitional Justice and Development: Making Connections (New York, Social Science Research Council, 2009). See also the forthcoming collection P Zumbansen and R Buchanan (eds) Law in Transition: Development, Rights and Transitional Justice (Oxford, Hart Publishing, 2013). 
vibrant 'literary"29 and cultural engagement with 'transition' periods. After the seminal (inevitably colonial) portrayals by Joseph Conrad in 'An Outpost of Progress' (1897) or 'Heart of Darkness' (1899), post-colonial novels such as Chinua Achebe's 'Things Fall Apart' (1958) and JM Coetzee's 'Waiting for the Barbarians' (1980) have again poignantly scrutinised the slippery slope between 'us' and 'them' that inescapably pervades any 'intervention' or 'development' context. How in the context of public international law's attempts to address transnational military and civil conflict, this slope has become painfully obvious again, was powerfully illustrated in Anne Orford's critique of the hidden, hegemonic aspirations of recent instances of 'humanitarian intervention'. 30 Excavating the challenges of concepts such as 'change', 'reform' and 'progress', as they have been central to seminal transitional justice debates as those concerning South Africa ${ }^{31}$ or Sri Lanka, ${ }^{32}$ Achmat Dangor's 'Bitter Fruit' (2001) or films such as Vithanage's Death on a Full Moon Day, have become inseparably intertwined with the scholarly, 'expert' discourse around these instances of transitional justice.

\section{The Transnational Space of the Contemporary 'Human Condition'}

What can this intersection of scholarly, literary, and cultural engagement tell us about the methodological challenges arising in the L\&D (and, transitional justice) context? To the degree that we can already build on a host of critical work to scrutinise the orientation, method, and contentions of L\&D and Transitional Justice (TJ) theory, an additional aspect of this enterprise concerns the acknowledgement of and engagement with non-scholarly content. Another question concerns the demarcation of places and spaces in this context. What, we may ask, distinguishes the focus of Achmat Dangor's poignant analysis of family relations in post-Apartheid South Africa $^{33}$ from the haunting account of Mourid Barghouti's return to Palestine after an involuntary 30 -year exile? ${ }^{34}$ Emerging, from these accounts, is a powerful illustration of what we might call the 'transnational human condition', marked by multilayered and multi-tiered relations of belonging and 'citizenship'. It is this dimension of the 'human condition' that could arguably be seen as the fourth dimension of Hannah Arendt's depiction of labour-work-action, ${ }^{35}$ scrutinising the possibilities of political, social belonging in a post-national environment, which is marked by the fragility of political communities and, again, an increased precariousness of political voice. ${ }^{36}$

Chinua Achebe, the author of the seminal novel 'Things Fall Apart' (1958), recounts in his 2009 collection of short stories, 'The Education of a British-Protected Child', numerous

\footnotetext{
${ }^{29}$ See the insightful discussion of the prose/poetry debate in India around the work of Rabindranath Tagore, in D Chakrabarty, Provincializing Europe: Postcolonial Thought and Historical Difference, 2nd ed. (first published 2000, Princeton, Princeton University Press, 2007).

${ }^{30}$ A Orford, 'Muscular Humanitarianism: Reading the Narratives of the New Interventionism' (2003) 10 European Journal of International Law 679.

${ }^{31}$ H Corder, 'Prisoner, Partisan and Patriarch: Transforming the Law in South Africa 1985-2000' (2002) 118 The South African Law Journal 772; A Gross, 'Reconciliation in South Africa' (2004) 40 Stanford Journal of International Law 40.

${ }^{32}$ J Derges, Ritual and Recovery in Post-Conflict Sri Lanka (London, Routledge, 2012).

${ }^{33}$ A Dangor, Bitter Fruit (Cape Town, Kwela Books, 2001).

${ }^{34}$ M Barghouti, I Saw Ramallah (London, Bloomsburry, 2004).

${ }^{35}$ H Arendt, The Human Condition (Chicago, Chicago University Press, 1958).

${ }^{36}$ See R Cotterrell, 'Spectres of Transnationalism: Changing Terrains of Sociology of Law' (2009) 36 Journal of Law and Society 481 and N Fraser, Scales of Justice: Reimagining Political Space in a Globalizing World (New York, Columbia University Press, 2009).
} 
instances in which he and the audiences he speaks before, are confronted with the porosity of the lines that divide 'home' and 'abroad', the 'here' and the 'there'. In Achebe's rendering, these experiences illustrate the tensions in people's lives when trying to make sense of their deeply felt attachments to places of origin, places of meaning, when - at the same time - they find themselves on an inchoate and often swirling trajectory, which takes them through different places, communities, spheres of interaction, places of engagement and confrontation - with others, who have come to these places through similar patterns of predictable unpredictability. Achebe's stories recount numerous instances of frustration in the face of alienation, cliché and stereotype that seem to repeat themselves - over and over again. The author presents them in an uncompromisingly and tirelessly analytical manner, the various accounts underlining the importance of difference in that which seems to be the same, the varying conjectures of people's meetings, confrontations and clashes of viewpoints and observations that cannot be so simply traced back, as emerges from story to story, to one particular stance, one easily demarcated political viewpoint or a comprehensively founded moral choice. Instead, Achebe highlights the numerous cross-roads in people's perceptions and judgments, the complex overlapping of context and intent that shape the moment where one formulates and utters one's view. He seems to say 'Look again', 'Think again' and 'Look again', and it is this back and forth wandering of our gaze, which may help to better grasp the challenges in contemporary L\&D and TJ contexts. These contexts are intricately marked by the simultaneous existence of the 'new' and the 'old'. And yet we are asked to reject this (overly neat) juxtaposition for the ways in which it imposes an evolutionary narrative of progress onto a sphere that needs to be studied through its complex relationship between local and global consciousness. ${ }^{37}$ Similarly, both L\&D and TJ become mere instantiations of a renewed effort to reflect critically on the methodological basis of legalpolitical governance.

David Trubek's immensely rich body of scholarly work, developed over the span of many years, is a very appropriate platform for the launching of such a renewal. The subject matter of this work has been intricately located in different places and in different spheres of conceptual imagination. As in Achebe's accounts, these spaces are both geographical and intellectual, both real and constructed. And, as is highlighted by the scholarship in the area of L\&D that David Trubek has himself significantly shaped, challenged and helped to establish and sustain, the critical engagement with these allegedly dividing lines between 'real' and 'constructed', between, say, field work, empirical data, news reports and statistics on the one hand and description, critique, deconstruction, and argument, on the other, are at the core of what L\&D is really all about. To both emphasise and simultaneously question the categories by which we draw lines between 'here' and 'there', 'home' and 'abroad', 'ours' and 'theirs', becomes a life's occupation, one that is only inadequately captured by a faculty website indication of 'law and development' as being someone's 'interest' or 'field of research'. Seen, studied, theorised and practiced in this critical way, L\&D becomes an instantiation of a much more comprehensive engagement with the 'concept of law', with the categories by which in research and curriculum lines are drawn between 'domestic' and 'foreign' laws and legal cultures. Thus, a scholar of L\&D of this calibre inevitably is a threat to the standards and routines of scholarship as it is carried out in law reviews and conferences and as it, in myriad ways, influences and shapes law school course design and the programming of legal education. The particular approach here taken to L\&D threatens the daily routine of law schools pretending to teach their fee-paying clients to 'learn to think like a lawyer' as it scrutinises this entire routine and suggests that it

\footnotetext{
${ }^{37}$ D Chakrabarty, Provincializing Europe (n 28), ch. 5 'Birth of the Subject'.
} 
could all be in fact very different if only we cared to reflect more on the connections between 'here' and 'there'. As is clear from Achebe's stories, to think about these connections is a tiresome business, one that must remain cautious, self-critical and never-satisfied, one that continues to draw on a wide spectrum of information, data, accounts - in other words, on a complex body of 'knowledge', on which one draws and to which one already and constantly contributes.

\section{Knowledge in Development}

The vibrant and increasingly intersecting intellectual discourses around the conceptual and

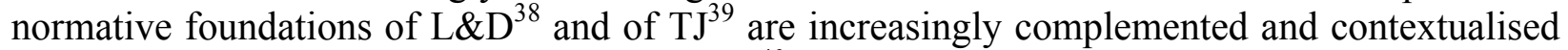
by a critical engagement with the North's ${ }^{40}$ legal regulatory as well as epistemological interventions in the 'South'. ${ }^{41}$ Arising from this attention to L\&D and TJ is an intensified interest in the nature of knowledge implicated in these different engagements. Knowledge becomes a crucial variable as it applies to a host of divergent conceptual and normative programs. For example, knowledge is at the heart of the expertise and 'know-how' retained by a governing body or drawn upon by governmental actors when crafting regulatory instruments and interventions. ${ }^{42}$ At the same time, knowledge as a variable and an unknown enters both sides of regulatory interventions - pertaining to what the regulator knows and what is known within the sphere acted upon. This double contingency of what law should know but can never know for certain, has long been a concern of legal regulatory theory, and of legal sociology and criminology in particular. ${ }^{43}$ Given the complex interplay of domestic and transnational governance discourses and the centrality of knowledge in both, ${ }^{44}$ the intensified interest in scrutinising what we know when unleashing programs of aid, reform as well as 'technical' and legal assistance has to be central to any future engagement with L\&D and TJ as part of a larger,

\footnotetext{
${ }^{38}$ See the contributions to DM Trubek and A Santos (eds), The New Economic Law and Development (n 8).

${ }^{39}$ N Roht-Arriazza, The Pinochet Effect: Transnational Justice in the Age of Human Rights (Philadelphia, University of Pennsylvania Press, 2005); N Roht-Arriazza and J Mariezcurrena (eds), Transitional Justice in the Twenty-First Century: Beyond Truth Versus Justice (Cambridge, Cambridge University Press, 2006); R Nagy, 'Transitional Justice as Global Project: Critical Reflections' (2008) 29 Third World Quarterly 275; S Vieille, 'Transitional Justice: A Colonizing Field?' (2012) 4 Amsterdam Forum 58.

${ }^{40}$ This depiction is used to mark both economic and ideological characteristics rather than a geographic region.

${ }^{41}$ B de Sousa Santos, 'Beyond Abyssal Thinking: From Global Lines to Ecologies of Knowledge' (Eurozine, 29 June 2007). See also the contributions to B d Sousa Santos (ed) Another Knowledge is Possible: Beyond Northern Epistemologies (London, Verso, 2007), and Radha D'Souza, 'Imperial Agendas, Global Solidarities, and Third World Socio-legal Studies: Methodological Reflections' (2012) 49:3 Osgoode Hall Law Journal 409.

${ }^{42}$ S Jasanoff, Science at the Bar: Law, Science, and Technology in America (Cambridge MA, Harvard University Press, 1997); see also the contributions to G Edmond (ed) Expertise in Regulation and Law (Aldershot, Ashgate, 2004).

${ }^{43}$ KN Llewellyn, 'The Normative, the Legal, and the Law-Jobs: The Problem of Juristic Method' (1940) 49 Yale Law Journal 1355; N Luhmann, 'Some Problems with Reflexive Law' in G Teubner and A Febbrajo (eds), State, Law and Economy as Autopoietic Systems (Milan, Giuffre, 1992) 389; P Zumbansen, 'Law's Effectiveness and Law's Knowledge: Reflections from Legal Sociology and Legal Theory' (2009) 10 German Law Journal 417.

${ }^{44} \mathrm{KW}$ Abbott and D Snidal, 'Strengthening International Regulation Through Transnational New Governance: Overcoming the Orchestration Deficit' (2009) 42 Vanderbilt Journal of Transnational Law 501; P Zumbansen, 'The Ins and Outs of Transnational Private Regulatory Governance: Legitimacy, Accountability, Effectiveness and a New Concept of "Context"' (2012) 13 German Law Journal 1269.
} 
interdisciplinary theory of global governance. ${ }^{45}$ From the vantage point of a critical engagement with knowledge, such an enterprise must develop a methodology able to open up, rather than eclipse avenues of contestation and mutual learning. ${ }^{46}$ A central contention in this paper is that the parallels and shared interests in contemporary L\&D and TJ discourses are echoed by the connections between domestic and transnational governance discourses. Where we find that L\&D discourses are inseparably intertwined with TJ-related questions regarding the appropriate and non-universalising, ${ }^{47}$ legal/non-legal response to legacies of suppression, exploitation and domination, we are confronted with the co-evolutionary dynamics of legal/non-legal, hard/soft, formal/informal. In short, attending to knowledge points us to the legal pluralist of modes of governance characteristic in settings which we have hitherto tended to study through conventional notions of jurisdiction, that is, through legal spatial lenses. ${ }^{48}$ However, these coevolutionary dynamics between L\&D and TJ support the emergence of regulatory regimes which can no longer adequately be captured through categories of state sovereignty or jurisdiction. Instead, the emerging transnational regulatory landscape follows to a large degree the fragmenting dynamics of a functionally differentiated world society, prompting, in turn, an intensified investigation as to the legitimacy, that is, the normative and political implications of the systems theory's world society model. ${ }^{49}$

These debates provide a formidable background to the continuously evolving debate around L\&D in that they complement and expand the highly charged economic and political stakes in this arena. David Trubek's work is of central significance in this regard. His interest in 'knowledge' occupies a crucial place in a long engagement with bridging both national and development governance discourses. An acute sensitivity to the ambiguous role of knowledge has informed his work over the decades, but in the following, I want to focus particularly on his emphasis on the role of knowledge in development processes as articulated in his recent papers on the 'new developmental state'. Taking a closer look at the role of knowledge in the L\&D context promises important insights into the future trajectory of this field in the above-sketched context of interdisciplinary global governance studies. What drives and motivates developments such as the World Bank's self-description as a 'Knowledge Bank' becomes a matter of critical concern, and prompts our reflection on the origins as well as the experiences that have already been made with such data-driven governance approaches in other places and times. In other

\footnotetext{
${ }^{45}$ D Held, 'Reframing Global Governance: Apocalypse Soon or Reform!' in D Held and A McGrew (eds), Globalization Theory: Approaches and Controversies (Cambridge, Polity, 2007) 240; FE Johns, 'Global Governance: An Heretical History Play' (2004) 4 Global Jurist Advances Art. 3.

${ }^{46}$ See, eg, JN Pieterse, 'Globalization North and South: Representations of Uneven Development and the Interaction of Modernities' (2000) 17 Theory, Culture \& Society 129; M-R Trouillot, The Anthropology of the State in the Age of Globalization: Close Encounters of the Deceptive Kind (2001) 42 Current Anthropology 125; J Ferguson and A Gupta, Spatialising States: Toward an Ethnography of Neoliberal Governmentality (2002) 29 American Ethnologist 981.

${ }^{47}$ S Vieille, 'Transitional Justice: A Colonizing Field?' (2012) 4 Amsterdam Forum 58.

48 J Ferguson and A Gupta, 'Spatialising States' (n 46); A Mbembe, 'At the Edge of the World: Boundaries, Territoriality, and Sovereignty in Africa' (2000) 12 Public Culture 259.

${ }^{49}$ This tension characterises the interchange between, say, Gunther Teubner and Emilios Christodoulidis. See G Teubner, 'Fragmented Foundations: Societal Constitutionalism beyond the Nation State' in P Dobner and M Loughlin (eds), The Twilight of Constitutionalism? (Cambridge, Cambridge University Press, 2010) and the contributions of Emilios Christodoulidis, Gert Verschraegen, Bart Klink, and Wil Martens in (2011) Netherlands Journal of Legal Philosophy, no 3. For Gunther Teubner's most recent, comprehensive attempt to engage with the challenge of normativity, see his monograph, G Teubner, Constitutional Fragments (Oxford, Oxford University Press, 2012).
} 
words, David Trubek's interest in the role of knowledge in today's development scholarship and practice - invites us to take a closer look at the connections and differences between the prominence of knowledge in this context and in domestic contexts in the past. To do so seems especially opportune in light of the crudeness of assertions, distinctions and categories that continue to characterise global governance discourses; particularly in terms of the descriptions and analysis of constellations that really deserve a more comprehensive and sophisticated conceptual treatment. ${ }^{50}$ Indeed, the persistence of inadequate analytic categories in the field of global governance is at considerable odds with contemporary analysis of knowledge-driven governance. ${ }^{51}$ Knowledge as an analytic category, particularly as informed by Trubek's work, offers us a way forward.

\section{A. The Boundaries of 'Law \& Development'}

While never having gained its secured and unquestioned seat in the core, mainstream NorthAmerican law school classroom curriculum, 'Law \& Development' has long been one of the most innovative, contested and actively discussed theory/practice laboratories to think about a whole range of dimensions of 'law reform', 'aid', 'development', 'progress' and 'growth', 'universality'/'relativism', 'imperialism', 'post-colonialism' and models of 'state' and 'society'. Among such laboratory work have always been efforts to question the foundations and in/adequacies of 'Western'/'Northern' regulatory concepts for 'developing' countries, fully exposing the deeply problematic and contestable nature of any such progress-associated connotations in the first place. Obvious, then, to participants in such work, was the inseparability of law critique in a 'foreign', distant place and 'at home'. In both contexts, inevitably, scholars would come to realise the fragile and intricate dynamics of 'their' legal orders' evolution, institutionalisation and function. It is sobering to note as well that in both contexts, scholars would come to realise the illusory nature of the separation of these contexts - foreign and domestic - , and how crucial the critical reflection on the boundaries of 'locality' must be. ${ }^{52}$

Despite the 'death knell' that was allegedly struck for 'the law and development movement' by Trubek's and Galanter's impressive self-critique in 1974, ${ }^{53}$ the consequences of their writing were, arguably, to enliven and galvanise a field of inquiry. Even if measured only by that inadequate measure - the number of citations, - their article has made a most important mark. Its analysis continues to trouble and problematise many different areas of legal discourse - well beyond the field of law \& development per se. How can this be explained? As alluded to at the beginning of this paper, there is a particular quality of scholarship which distinguishes itself by making ambitious theoretical, conceptual and political claims based on a careful and comprehensive engagement with a well-considered, complex literature. As such, the value of that scholarship endures beyond the narrow window of a current moment. An engagement with Max Weber, for example, becomes a comprehensive and lasting exploration of the complex relations between legal thought and political governance, ${ }^{54}$ a scathing self-critique

\footnotetext{
${ }^{50}$ RA Posner, 'Creating a Legal Framework for Economic Development' (1998) 13 The World Bank Research Observer 1.

${ }^{51}$ K-H Ladeur, 'Constitutionalism and the State of the "Society of Networks": The Design of a New "Control Project" for a Fragmented Legal System' (2011) 2 Transnational Legal Theory 463.

${ }^{52}$ DM Trubek and M Galanter, 'Scholars in Self-Estrangement' (n 8).

${ }^{53}$ S Pahuja, Decolonising International Law (n 12), 204, n.152.

${ }^{54}$ DM Trubek, 'Max Weber's Tragic Modernism and the Study of Law in Society' (1986) 20 Law \& Society Review 573.
} 
of the hitherto applied methodologies to comparison and law reform in the context of $1 \& \mathrm{~d}$ that unfolds into an inspiring inquiry into the role of law in society. ${ }^{55}$

This elevation of the bar can also be seen in more recent work, be that in the context of the complex regulatory arrangements of the European Union ${ }^{56}$ or of the much debated law reforms that are on the way in different parts of Latin America today. ${ }^{57}$ The promises - and rewards - of such work are not only keen and timely observations of present constellations of law and regulatory governance, but a better and more comprehensive understanding of the way in which lawyers must consciously draw on an increasingly differentiated and complex, interdisciplinary analysis of evolving governance structures if they want for law to retain a voice in the fast-evolving regulatory theory discourses. At the same time, such scholarship appreciates our 'standing on the shoulders of giants', less in devout reverence than in critical and alert appreciation of an ongoing, continuing conversation.

This research offers comprehensive insights into the complexities of political transformation, law reform and global integration through a reconnection of local knowledge with earlier and larger discursive frameworks. So, while focusing on one region of the world and a limited number of countries, it soon becomes obvious how immensely rich the tapped-into repository of information is. Trubek's more recent work on the evolving political economy of the 'new developmental state' forcefully connects a careful consideration of facts 'on the ground' with work on political economy, on state-market relations and on legal and regulatory governance. ${ }^{58}$ Against the background of a longstanding scrutiny of the methodological and conceptual challenges facing anyone engaged in law \& development work, he seeks to demarcate the contours of a political economy analysis in the development context. Poignantly, he comes to this analysis equipped with a toolbox containing both analytical and conceptual instruments, the adequacy and usefulness of which will have to be assessed in the very concrete applicatory context. In that vein, he observes that the "New Political Economy of Development" (NPED) assumes a central role of uncertainty in setting goals of industrial policy, designing and implementing market regulatory instruments and identifying level of global competitiveness of national economy.' The use of the concept of the 'process of discovery' to explain the regulatory approach in the NPED, owed but not attributed to Hayek, ${ }^{59}$ puts the finger on the sensible spot of the - constructed! - boundaries of state-market or, public-private. 'If we wanted to sum up the NPED in a few words, it might be in envisioning development as a process of discovery in which the state seeks to empower the private sector and state and market function best when they are linked in collaborative structures that foster experimentation and revision. ${ }^{60}$ Hic sunt leones! Well aware of the beasts lingering in the shadow of volatile and vulnerable governance structures, coming in the form of institutional economists and 'social norm' theorists, Trubek directs our attention to a body of theoretical work that explicitly aims at bringing together economics, law and politics in order to address real-world problems.

\footnotetext{
${ }^{55}$ DM Trubek and M Galanter, 'Scholars in Self-Estrangement' (n 8).

${ }^{56}$ DM Trubek and L Trubek, 'Hard and Soft Law in the Construction of Social Europe (n 7).

${ }^{57}$ DM Trubek, 'Developmental States and the Legal Order: Towards a New Political Economy of Development and Law' (2008) University of Wisconsin Legal Studies Research Paper No. 1075

${ }^{58}$ Trubek (n 13).

${ }^{59}$ FA Hayek, 'Competition as a Discovery Procedure' (first published 1968, MS Snow tr)' (2002) 5 Quarterly Journal of Austrian Economics 9; see also F Hayek, 'The Use of Knowledge in Society' (1945) 35 American Economic Review 519.

${ }^{60}$ Trubek, Developmental States and the Legal Order (n 8), 10.
} 
A detailed example of the new kinds of institutions and policies can be found in Hausmann, Rodrik, and Sabel's proposal for industrial policy. This proposal reflects the underlying assumptions of the new development economics and illustrates the kinds of novel institutions it suggests. They note several features of developing country markets that lead to sub-optimal performance and justify state intervention. Such markets may fail to identify new products whose profitability creates positive externalities for the national economy; provide mechanisms to coordinate interrelated investments; or generate knowledge about the public inputs necessary for the success of an industry. To overcome these failures, they propose new approaches to the organization of an industrial policy. ${ }^{61}$

The responsibility falling on the state here is to 'organise a dialogue among the firms in a sector, region or industry and between the firms and the state; provide incentives for the provision of public inputs identified by this kind of collaboration; encourage continuous improvement; create a system to monitor the projects that emerge from the deliberations; and ensure that the fruits of learning through these processes are shared. ${ }^{, 62}$

Refreshingly candid in laying out the motivations of such an engagement, Trubek highlights how 'these institutional innovations have significant implications for the law-and vice versa.' His interest in this work on experimentalist governance and industrial innovation policy ${ }^{63}$ is driven by the idea that 'their proposals for public-private deliberation and specialised budgets for government input in selected industries will raise a series of administrative law and constitutional law issues. ${ }^{64}$ Against this background, however, Trubek exposes the ambitious claim of his engagement with these bodies of work:

I set forth a theory of the relationship between economic ideas and various doctrines in the field of law and development. The history of thought about law and development shows that there is an intimate relationship between prevailing economic ideas and dominant notions of the proper role of law in development. [...] This law and development doctrine is more than a simple recipe book of projects and less than an autonomous academic theory. Rather, as Alvaro Santos and $\mathrm{I}$ have argued, it is best seen as the product of the interaction of legal theory, economic development theory, and the practices of development agencies. ${ }^{65}$

It is here that we discern most clearly the range of theoretical discourses that, according to Trubek, are quintessential to resuscitating the troubled state of law \& development theory in a highly contested and volatile political and economic global context. However, focusing on a concrete case study presents challenges that loom even larger. Especially when it comes to developing a sound theoretical framework and drawing on locally gained and compared data:

[I]f evidence of [New Developmental State] NDS state practice is fragmentary, data on legal practices is almost non-existent and the theory of law in the new developmental state has not yet been created. But we would expect that among

\footnotetext{
61 ibid. 12 .

62 ibid, 13.

${ }^{63}$ See R Hausmann, D Rodrik and CF Sabel, 'Reconfiguring Industrial Policy: A Framework with an Application to South Africa' (2008) Harvard University Center for International Development CID Working Paper No. 168, available at www.hks.harvard.edu/centers/cid/publications/faculty-working-papers/cid-working-paper-no.-168.

${ }^{64}$ Trubek, Developmental States and the Legal Order (n 8), 13.

65 ibid, 16.
} 
other things we will find a great deal of interest in creating the legal framework for various forms of public-private collaboration; emphasis on creating the legal structure for a kind of capital market that can identify and reward entrepreneurship; attention to shifts in corporate governance to encourage investment and promote innovation; recognition of the need for flexibility and for ways to encourage experimentation; and efforts to challenge any aspect of international economic law that might hinder state intervention. ${ }^{66}$

Arguably, the gist of this effort lies, as noted before, in a building on and on an approximation of development theory with economic theory, above all institutional economics, with industrial innovation policy theory as well as with 'new governance', among which experimental governance occupies a prominent place. This suggestion prompts a number of comments. First, it should be emphasised that Trubek's purposive engagement with complex theoretical approaches is a powerful illustration of the challenges facing both theory and practice in the presence of complex regulatory arrangements today. Yet, every toolkit itself has a history of its own, the way it came to be put together, the order of instruments that are stored and arranged on its inside, and the use that has been made of them over time - their application in practice. While this is an obvious point to make, it deserves mentioning in the L\& D context, which prompts a host of questions regarding the origin, adequacy and transferability of regulatory models. Similar to the seemingly never-ending self-inspection and critique of comparative law, ${ }^{67} \mathrm{~L} \& \mathrm{D}$ is a field forever belaboured and challenged on a complex methodological basis. The following section raises a number of questions in response to the proposal of importing political economy concepts into the study of developing governance structures, as suggested in David Trubek's recent work.

The previous references underscore the relevance of approaching a study of a local regulatory culture from a more comprehensive perspective that allows for a scrutiny of the actors, norms and processes, which shape the development context. ${ }^{68}$ But, at the same time, I would like to voice a concern regarding the baggage and background assumptions, accompanying and shaping the political economy ideas transplanted from one context - a postIndustrialist and post-Welfare constitutional state - into another context with institutional and normative dimensions which we might not be able to map with the cartography we are used to. This seems to be of particular importance with regard to the implicit assumptions informing an endorsement of regulatory models such as decentralisation, innovation and regulatory competition. In political and regulatory theory discourses of the last two to three decades, these terms emerged in an intricate intellectual space between economic and political theories and have by now attained an almost sacrosanct character, be that with regard to federal structures in complex polities $^{69}$ or in the context of searching for growth models in path-dependent

\footnotetext{
${ }^{66}$ ibid, 18-19.

${ }^{67}$ See now the contributions to M Adams and J Bomhoff (eds), Practice and Theory in Comparative Law (Cambridge, Cambridge University Press, 2012).

${ }^{68}$ For more background on the A-N-P approach, see P Zumbansen, 'Lochner Disembedded: The Anxieties of Law in a Global Context' (2012) 20:1 Indiana Journal of Global Legal Studies, forthcoming, available at http://ssrn.com/abstract=2174017.

${ }^{69}$ S Rose-Ackerman, 'Risk Taking and Reelection: Does Federalism Promote Innovation?' (1980) 9 Journal of Legal Studies 593; GA Bermann, 'Harmonization and Regulatory Federalism' in I Pernice (ed) Harmonization of Legislation in Federal Systems (Baden-Baden, Nomos, 1996); R Howse and K Nicolaidis (eds), The Federal Vision (Oxford, Oxford University Press, 2001); B Galle and J Leahy, 'Laboratories of Democracy? Policy Innovation in Decentralized Governments' (2009) 58 Emory Law Journal 1333.
} 
economies. $^{70}$ However, as examples of transatlantic transplants already illustrate, the effects of policies that endorse a fine-tuned subsidiarity-federalist framework and that place hope into the regulated self-regulatory dynamics of actors on different levels ${ }^{71}$ greatly depend on the historically and politically evolved context in which they are implemented. What might be in itself a very promising conceptual approach to the study of multi-level and multi-polar regulatory systems - and the EU certainly represents just that ${ }^{72}$ — will eventually unfold through highly intricate and unpredictable dynamics in a continuously evolving complex environment. ${ }^{73}$

To be sure, it is no more than a trivial insight that these experiences suggest the need to pay close regard to the locally existing rules and regulatory practices - the challenge consists in determining the form and process of 'context sensitive' regulation. It is with this challenge in mind, that we are finding ourselves torn between opening our toolbox of well-worn and tested tools and concepts on the one hand and starting 'fresh', with open eyes and without prejudice on the other. ${ }^{74}$ What is remarkable in this context is the impossibility of 'breaking free' even from the semantic and symbolic stronghold of certain categories, regardless of the degree to which these have been subjected to critique, deconstruction and demystification. This is as true today ${ }^{75}$ as it was in the 1970s: ${ }^{76}$ in our search for appropriate regulatory approaches to be taken with regard to development contexts (as well as other, similarly complex regulatory spaces ${ }^{77}$ ), we strive to critically reflect on the usability of the rule of law, learned lessons with regard to democratic accountability, public deliberation or the separation of powers. Meanwhile, we realise how none of these principles can be lifted out of its context without losing some explanatory capacity, leading us back to the motivation of why we intended to draw on a particular regulatory experience in the first place. Again and again, we are confronted with the particularity of an evolutionary process in a specific space that seemingly frustrates all attempts

\footnotetext{
${ }^{70}$ W Lazonick, 'Varieties of Capitalism and Innovative Enterprise' (2007) 24 Comparative Social Research 21; JP Murmann, Knowledge and Competitive Advantage: The Coevolution of Firms, Technology and National Institutions (Cambridge, Cambridge University Press, 2003).

${ }^{71}$ CF Sabel and J Zeitlin, 'Learning from Difference: The New Architecture of Experimentalist Governance in the EU' (2008) 14 European Law Journal 271; see already MC Dorf and CF Sabel, 'A Constitution of Democratic Experimentalism' (1998) 98 Columbia Law Review 267.

72 See, eg, G Majone, 'The European Commmunity Between Social Policy and Social Regulation' (1993) 31 Journal of Common Market Studies 153, and KA Armstrong, 'Governance and the Single European Market' in P Craig and $\mathrm{G}$ de Búrca (eds), The Evolution of EU Law (Oxford, Oxford University Press, 1999).

${ }^{73}$ R Boyer and JR Hollingsworth, 'From National Embeddedness to Spatial and Institutional Nestedness' in JR Hollingsworth and R Boyer (eds), Contemporary Capitalism: The Embeddedness of Institutions (Cambridge, Cambridge University Press, 1997); R Dore, W Lazonick and M O'Sullivan, 'Varieties of Capitalism in the Twentieth Century' (1999) 15 Oxford Review of Economic Policy 102; G Teubner, 'Legal Irritants: How Unifying Law Ends Up In New Divergences' in PA Hall and D Soskice (eds), Varieties of Capitalism: The Institutional Foundations of Comparative Advantage (Oxford, Oxford University Press, 2001); P Zumbansen, "'New Governance" in European Corporate Governance Regulation as Transnational Legal Pluralism' (2009) 15 European Law Journal 246.

${ }^{74}$ See, eg, K Pistor, 'Of Legal Transplants, Legal Irritants, and Economic Development' in P Cornelius and B Kogut (eds), Corporate Governance and Capital Flows in a Global Economy (Oxford, Oxford University Press, 2003).

${ }^{75}$ K Rittich, 'The Future of Law and Development: Second Generation Reforms and the Incorporation of the Social' (2004) 26 Michigan Journal of International Law 199.

${ }^{76}$ DM Trubek and M Galanter, 'Scholars in Self-Estrangement' (n 8).

${ }^{77}$ N Krisch, Beyond Constitutionalism. The Pluralist Structure of Post-national law (Oxford, Oxford University Press, 2010), ch. 4.
} 
at translation or transplantation. ${ }^{78}$ And yet, precisely because of this confrontation, we return, again and again, to a critical reflection on the categories through which we seek both to explain and to shape spaces of vulnerability and precariousness. There appears to be a crucial difference, however, between an earlier, progressive, critical exercise of such reflection and the more inchoate, interdisciplinary approach that seems to be forming today out of a combination of legal, political, sociological, economic and anthropological theory on the one hand and historical and linguistic study on the other. ${ }^{79}$ While this difference is still hard to pinpoint or to make fruitful, it becomes ever more evident that in close proximity to the continuing stand-offs between conservative and progressive struggles over development policies, the range of theory, vocabulary and categories, frameworks and imaginations is expanding. In that context, the astutely recorded accounts by Achebe of his interactions with 'third world experts, ${ }^{80}$ the extermination of interview protocols and legislative materials of law-making processes in Singapore's 'authoritarian' Rule of Law ${ }^{81}$ or the anthropological scrutiny of the World Bank's human rights programs ${ }^{82}$ - they are all and each one of them crucial elements that help draw a richer and more sophisticated picture of the development context today. In other words, we see a significant analytical expansion and deepening of our 'knowledge' basis vis-à-vis the developmental state and the transnational 'aid and development' apparatus that is staring at it. The challenge remains in understanding and drawing the adequate lessons of such an expanding epistemic framework. The remainder of this contribution shall briefly touch on three categories that play an enormous - both practical and symbolic - role in development discourses today: market, constitution and knowledge.

\section{B. Semantic Tools of Power and Domination: Market, Constitution, Knowledge}

Questions related to the order and selection of 'tools' come to the surface not only in the context of the re-introduction of (Hayek's) idea of a discovery process marking the spontaneous selforganising dynamics of markets, ${ }^{83}$ but in every assertion of the benefits of regulatory competition in comparison to harmonisation models. Self-regulation, decentralisation and empowerment of actors - as governance subjects — are frameworks which linger alluringly in the background and inform the reference to the promise of discovery as a governance principle. However, turning one's gaze away from the development context here under scrutiny and back towards the current applicatory contexts where we find long-standing and recently recurring references to discovery, illustrates some of the baggage associated with this idea. Drawing on Hayek, but also

\footnotetext{
${ }^{78}$ GA Sarfaty, 'Measuring Justice: Internal Conflict over the World Bank's Empirical Approach to Human Rights' in K Clarke and M Goodale (eds), Mirrors of Justice: Law and Power in the Post-Cold War Era (Cambridge, Cambridge University Press, 2009).

${ }^{79} \mathrm{~J}$ Rajah, Authoritarian Rule of Law: Legislation, Discourse and Legitimacy in Singapore (Cambridge, Cambridge University Press, 2012), 37-52, 58-60, 288.

${ }^{80} \mathrm{C}$ Achebe, The Education of a British-Protected Child (New York, Knopf, 2009).

${ }^{81}$ Rajah, Authoritarian Rule of Law (n 79), 181-212.

${ }^{82}$ SE Merry, 'Measuring the World: Indicators, Human Rights, and Global Governance' in P Zumbansen and R Buchanan (eds), Law in Transition: Rights, Development and Transitional Justice (Oxford, Hart Publishing, 2013 forthcoming); GA Sarfaty, Values in Translation: Human Rights and the Culture of the World Bank (Palo Alto, Stanford University Press, 2012).

${ }^{83}$ For a fuller exposition, see FA Hayek, The Constitution of Liberty (first published 1960, London, Routledge, 2006).
} 
on Tiebout, ${ }^{84}$ private lawyers, economists and regulatory theorists have been insisting for some time on the supremacy of a regulatory competition approach in contrast to harmonisation or unity-based concepts of market regulation. ${ }^{85}$ This deserves mention merely to shed some light on the alluring power of both discovery process and regulatory competition even in discourses that otherwise would have been believed to be firmly in the hands of legal scholars, particularly constitutional and administrative lawyers. (On a side note, teaching Tiebout and Hayek to law students interested in studying the concept of constitutional order, they usually don't notice that they are not even reading a legal text. Only after being exposed to a critical legal voice laying bare the implicit assumptions, do students catch their breath). ${ }^{86}$

The challenges of employing the idea of regulatory competition in an economic sense are reiterated in Trubek's observation that ' $[\mathrm{t}]$ he new developmental state seems to need both flexibility and stability.' The commitment to experimentation 'creates a need for flexible, specialised, and easily revisable frameworks. ${ }^{87}$ It is now an obvious point to make, and Trubek is among the first to acknowledge the treacherousness of endorsing a regulatory framework per se - as it were, rather than in placing it in a particular context that gives it meaning and contours. The endorsement of flexibility and adaptable, 'revisable' frameworks is one, which follows closely on the regulatory experiences in post-Welfare State political economies in the North and the West, have altogether been marked by a significant shift away from substantive, activist rule-of-law conceptions, in which governments would confidently employ legal regulation to further an abundance of social goals. The fundamental transformation of the welfare state ${ }^{88}$ opened up a plethora of options on the right and the left, with law and economics eventually coming out as the most successful among the emerging 'law and society' methodologies. ${ }^{89}$ The dominance of governance theory that places the market at the centre of its regulatory design has been relatively unabashed over the decades since the 1980s, and even the current financial and economic crisis does not yet seem to have induced its demise. At the same time, we see that engagements with 'market' as governance category are untiring. Apart from the only temporarily soothing references to Polanyi ${ }^{90}$ we are drawn to explore the intricacies of transnationally constituted markets through an interplay of economic, sociological and regulatory theory. This interplay draws our attention to the dynamics between market processes and

\footnotetext{
${ }^{84}$ CM Tiebout, 'A Pure Theory of Local Expenditures' (1956) 64 Journal of Political Economy 416.

${ }^{85}$ See, eg, J Macey, 'Regulatory Globalization as a Response to Regulatory Competition' (2003) 52 Emory Law Journal 1352, or PB Stephan, 'Regulatory Cooperation and Competition: The Search for Virtue' in GA Bermann, M Herdegen and PL Lindseth (eds), Transatlantic Regulatory Co-operation (Oxford, Oxford University Press, 2000), 167-202; for a poignant critique, see S Deakin, 'Reflexive Governance and European Company Law' (2007) CLPE Research Paper Series and Cambridge Centre for Business Research Working Paper No. 346.

${ }^{86}$ D Charny, 'Illusions of a Spontaneous Order: "Norms" in Contractual Relationships' (1996) 144 University of Pennsylvania Law Review 1841.

${ }^{87}$ Trubek, Developmental States and the Legal Order (n 8), 20.

${ }^{88}$ P Pierson, 'The New Politics of the Welfare State' (1996) 48 World Politics 143.

${ }^{89}$ K Rittich, 'Functionalism and Formalism: Their latest Incarnations in Contemporary Development and Governance Debates' (2005) 55 University of Toronto Law Journal 853, 857: 'We know that functionalist arguments can be flipped, and that both law and economics and critical legal studies are realist progeny'.

${ }^{90}$ See, eg, N Fraser, 'The Crisis of Capitalism' Lecture before the 'Normative Orders' Research Cluster, GoetheUniversity, Frankfurt, 19-20 April 2010, available atwww.normativeorders.net/de/veranstaltungen/dokumentation/videothek/415-frankfurt-lecture-ii; for further engagements with Polanyi in a transnational context, see the contributions to C Joerges and J Falke (eds), Karl Polanyi, Globalisation and the Potential of Law in Transnational Markets (Oxford, Hart Publishing, 2011).
} 
evolving organisational structures, ${ }^{91}$ and highlights the need for a better understanding of the interpenetration of economics and finance in the construction of today's markets. ${ }^{92}$ That such undertakings are now urgent is only underscored by the fast emergence of 'new' economies and the spatialisation of new, transnational markets. ${ }^{93}$ In 'response', we find a feverish search for regulatory frameworks, policies and processes, altogether forming the context and background for an assertion of market governance in developing countries. Those bad old times of a crude depiction of a 'legal framework for economic development' ${ }^{94}$ — they appear to have passed, or have they?

\section{The Constitutional Promise}

Responding to the seemingly ubiquitous constitutionalist discourse, which has been asserting its place within global governance debates, a group of scholars from Colombia, South Africa and India convened in 2011 in New York to explore the options of formulating a concept of constitutionalism 'from the global south'. The edited volume, which grew out of this meeting, and which is projected to be published later this year, is a most welcome contestation of the predominantly western discourse on 'global constitutionalism' so far. In his erudite introduction, the conference convenor and editor of the collected essays, Daniel Bonilla, highlights the ambiguities that characterise a research project on constitutionalism, which is perceived from a particular geopolitical and historical angle, but which can only be opened up to analysis if a whole other set of factors is taken into consideration. Such factors include the fact that through an extensive history of colonisation, a great number of constitutional principles were introduced into the legal orders now under scrutiny. At the same time, through the process of decolonisation and more recent legal transplants, the legal orders undergo a significant transformation, the result of which is in most cases an intricate combination of 'old' and 'new', 'northern' and 'southern' constitutional principles and instruments. Furthermore, the perception of the 'foreign' or 'southern' legal order is greatly influenced by the constitutional understandings that the observer brings to the task. Not only is this complexity aptly reflected in the introduction but the chapter also introduces the main actors in a north-south dialogue on comparative constitutionalism and constitutional reform. As regards the choice of the three countries under scrutiny in this book India, South Africa and Colombia - Professor Bonilla and the contributors to the book make the pertinent point that while there is less sense in trying to carve out a comprehensive and distinct framework for a constitutionalist approach of the global south, the chosen countries provide for representative case studies to illustrate the major traits of post-colonial constitutionalism. All three experiences are instantiations of a far-reaching and complex history of legal reform, offering rich insights into the negotiation between legislative and adjudicatory approaches to legal regulation in the face of great economic inequality, social and cultural diversity and violence. Studies such as these collected in the cited book allow for a more adequate, contextual

\footnotetext{
${ }^{91}$ See, eg, D Baecker, Wirtschaftssoziologie (Bielefeld, Transcript Verlag, 2006) and S Deakin, 'Corporate Governance and Financial Crisis in the Long Run' in P Zumbansen and CA Williams (eds), The Embedded Firm: Corporate Governance, Labour and Financial Capitalism (Cambridge, Cambridge University Press, 2011).

92 See, eg, R Dore, 'Financialization of the Global Economy' (2008) 17 Industrial and Corporate Change 1097 and E Engelen, 'The Case for Financialization' (2008) 12 Competition and Change 111, as well as S Jacoby, 'Labor and Finance in the United States' in CA Williams and P Zumbansen (eds) (note 91).

93 'BRICs, emerging markets, and the world economy — Not just straw men: The biggest emerging economies are rebounding, even without recovery in the West' (The Economist, 18 June 2009).

${ }^{94}$ RA Posner, 'Creating a Legal Framework for Economic Development' (1998) 13 The World Bank Research Observer 1.
} 
understanding of the legal, but also political and cultural issues involved. As such, this scholarship gives unparalleled insights into the local discourses, contestations of and engagements with political and judicial actors, scrutinising the tensions between 'activist' courts and governments, extrapolating the local structures and challenges of gaining 'access to justice' and the obstacles of unfolding an ambitious constitutional agenda in the context of dire economic — and political — inequality and social fragmentation.

This brief allusion to the - yet unpublished - essays in said volume should only point us in the direction of further differentiation when it comes to references to constitutional reform and the 'migration of constitutional standards', 95 especially in the development context. The value of interventions such as those alluded to here, can hardly be overstated, bringing as it were, to light the significant blind spots in a constitutional discourse that, while aspiring to 'global' relevance, remains too embedded in a particular, northern-western reference framework. ${ }^{96}$ The consequence of this perspective is a silently yet decisively lingering confidence in the 'embedding', 'containing' and 'empowering' function that constitutional law can assume in a context that is otherwise marked by significant regulatory fragmentation and precariousness. Without taking into account the very detail of an evolving constitutional culture in a particular social, historical, political and economic context, we are running the risk of blindly endorsing a specific understanding of rights or of constitutional protection that has only little if any relevance to the place it is being brought to. One of the authors in the cited volume, Professor Manuel Iturralde, cautions against foregone conclusions regarding the formation of a unified, coherent constitutional mindset of the 'global south'. Instead, he stresses some of the changes that occurred in Colombia, but also in other parts of the world, including in the global south. Among such changes was the rise of progressive constitutional thinking, a growing confidence in a strong judicial branch, "particularly in constitutional courts, as a valuable tool to attain social change.' Drawing on Diego López Medina's influential work on legal theory in Latin America, the author emphasises the decline in importance of legal formalism in comparison to 'new progressive - constitutionalism' and judicial activism. Importantly, the author cautions against the view that would perhaps too enthusiastically equate the judicial activism evidenced by the example of the Colombian Constitutional Court with real advance in social change. While acknowledging that court pronouncements by themselves cannot bring about social change (the lessons of Brown v. Board are deeply internalised), the author posits that judicial activism can and does produce 'instrumental' and 'symbolic effects'. In conclusion, the author finds that the Court's jurisprudence has contributed to an opening up of deliberative and democratic spaces...'

Surely, paradigm changes are not induced in a simple manner. As is sourly acknowledged from within the field of comparative law in general, ${ }^{97}$ constitutional comparisons are still plagued by a great degree of methodological uncertainty and theoretical indeterminacy. But,

\footnotetext{
${ }^{95}$ S Choudhry (ed) The Migration of Constitutional Ideas (Cambridge, Cambridge University Press, 2006).

${ }^{96}$ See, eg, the critical remarks by P Capps and D Machin, 'The Problem of Global Law' (2011) 74 Modern Law Review 794, reviewing N Krisch, Beyond Constitutionalism (n 75).

${ }^{97} \mathrm{O}$ Kahn-Freund, Comparative Law as an Academic Subject: Inaugural lecture delivered before the University of Oxford on 12 May 1965 (Oxford, Clarendon Press, 1965); O Kahn-Freund, 'On Use and Misuse of Comparative Law' (1974) 37 Modern Law Review 1; P Legrand, Le droit comparé (Paris, Presses Universitaires de France, 1999); RA Miller, 'Introduction' in S Reza, MJ Bazyler, RA Miller and P Yu (eds), Global Legal Traditions: Comparative Law in the Twenty-First Century (Dayton, Lexis Nexis, 2013 forthcoming).
} 
while '[c] onstitutionalism is sweeping the world', ${ }^{98}$ evidenced for example by 'at least 110 countries around the world' have engaged in constitution writing or reform since $1990,{ }^{99}$ this evidence is itself extremely varied. Both causes and forms of constitutional change are anything but uniform and thus belie all claims regarding a world-wide and universal trend to a specific set of constitutional values or rights. Rather, the intensity of constitutional creation, reform and discourse around the world is illustrative of the complexity of this process. The search, thus, for a better understanding of these myriad and continuously evolving constitutionalist cultures must reach deep into the constitutive elements of legal and political cultures, where the places, forms and scopes of democracy continue to be 'unsolved riddles'. ${ }^{100}$ As 'law and development' forms and reforms itself into an ever more comprehensive reflective framework to investigate the meaning and role of law in evolving societies, such locally informed studies of constitutionalism hold significant promise.

\section{The Elusive Nature of Knowledge}

Briefly returning to David Trubek's emphasis on the crucial role of knowledge in the conceptualisation of regulatory policy in the new developmental state, in this section we should touch upon some of the challenges in engaging with knowledge in this context. By way of provocation, I should like to posit that the greatest challenge in determining the role of knowledge in the development context lies in designing a process by which it would become possible to assess the type and quality of knowledge, which is being considered as relevant in the conceptualisation of regulatory policy. This 'process', however, is more than a mere procedural framework pertaining to methods of information gathering, 'consultations', timelines and 'evaluation'. Clearly, we are here confronted with much deeper issues regarding the assessment of the collected and evaluated data, issues that touch directly on the contested 'relevance' of any information ${ }^{101}$ and critically highlight the precarious basis on which both domestic ${ }^{102}$ and developmental ${ }^{103}$ policies are so regularly based. As such, our concern with contested knowledge connects related questions arising in the L\&D context with longstanding and still evolving debates in domestic and transnational regulatory spaces. Both are telling and relevant for an assessment of 'knowledge' in development, as northern/western regulatory experiences and mindsets routinely become transported into the development context, without the necessary reflection on the different contextual circumstances between the exporting and importing state. ${ }^{104}$

\footnotetext{
${ }^{98}$ SH Williams, 'Introduction: Comparative Constitutional Law, Gender Equality, and Constitutional Design' in SH Williams (ed) Constituting Equality: Gender Equality and Comparative Constitutional Law (Cambridge, Cambridge University Press, 2009), 1.

99 ibid.

${ }^{100} \mathrm{~S}$ Marks, The Riddle of All Constitutions: International Law, Democracy, and the Critique of Ideology (Oxford, Oxford University Press, 2000), 103, 146.

${ }^{101}$ See only M Valverde, 'Jurisdiction and Scale: Legal “Technicalities” as Resources for Theory” (2009) 18 Social \& Legal Studies 139 and M Valverde, Law's Dream of a Common Knowledge (Princeton, Princeton University Press, 2003), with a telling differentiation of 'small T' and 'large T' categorisations of truth.

${ }^{102}$ K-H Ladeur, 'The Evolution of General Administrative Law and the Emergence of Postmodern Administrative Law' (2011) 6 Osgoode Hall Law School CLPE Research Paper Series No. 16/2011.

${ }^{103}$ Rittich, (n 75); Merry, 'Measuring the World' (n 80).

${ }^{104}$ See, eg, A Santos, 'The World Bank's Uses of the "Rule of Law" Promise in Economic Development' in DM Trubek and A Santos (eds), The New Law and Economic Development, (n 8) and DM Trubek and M Galanter, 'Scholars in Self-Estrangement' (n 8).
} 
Among the many questions that arise against this background are those that relate to the process by which development agencies 'draw on', 'generate' and 'employ' information from which development programs and policies are being conceived and designed. Such perennially pressing and well-known ${ }^{105}$ questions now find a potentially fruitful echo in explorations of the way in which global governance institutions can themselves be 'opened' towards a broader basis of public participation, input and, eventually, accountability. Such investigations have been brought under way, more recently, ${ }^{106}$ under the umbrella of 'global administrative law' (GAL), and have unsurprisingly prompted a lively mix of endorsement and critical engagement. ${ }^{107}$ Whatever the continued debate over the real scope and usefulness of 'GAL'108 might produce, there is an important 'approximation' of previously too isolated discourses occurring here, which will arguably continue to expose the law of international organisations to contestation but, even more, move parallel critical discourses closer to this 'field'. As such, the Third World Approaches to International Law (TWAIL) scholarship ${ }^{109}$ has begun to open important vistas on the historical and semantic trajectories ${ }^{110}$ of international law and the order it both depicts and constructs. Similarly, the field of 'transitional justice' has recently begun to assume a more important role in the intellectual space of $L \& D$, given its concerns with evolving state structures and constitutional orders, frequently unfolding at the intersection between local fragmentation and foreign intervention. ${ }^{111}$

What these cursory references may highlight at least, is the complex basis of what might be considered to be 'relevant' knowledge in the context of development policy making and how such assertions are themselves always highly contested. ${ }^{112}$ The proliferation of contending and

${ }^{105}$ DM Trubek, 'The Owl and the Pussy-Cat: Is there a Future for “Law and Development”?' (2007) 25 Wisconsin International Law Journal 235.

${ }^{106}$ For a compelling account of the struggles in the conceptualisation of the Bretton Woods institutions, see Pahuja, Decolonising International Law (n 12), 14-25.

${ }^{107}$ See, eg, B Kingsbury, N Krisch and R Stewart, 'The Emergence of Global Administrative Law' (2005) 68 Law \& Contemporary Problems 15; of the numerous, insightful, critical engagements with this proposal, see, eg, C Harlow, 'European Administrative Law and the Global Challenge' in P Craig and G de Búrca (eds), The Evolution of EU Law (Oxford, Oxford University Press, 1999) and BS Chimni, 'Co-option and Resistance: Two Faces of Global Administrative Law' (2005) 37 New York University Journal of International Law \& Politics 799.

${ }^{108}$ My own concerns are expressed in P Zumbansen, 'Transnational Comparisons: Theory and Practice of Comparative Law as a Critique of Global Governance' in J Bomhoff and M Adams (eds), Theory and Practice of Comparative Law (Cambridge, Cambridge University Press, 2012).

${ }^{109}$ See the landmark studies by B Rajagopal, International Law from Below. Development, Social Movements and Third World Resistance (Cambridge, Cambridge University Press, 2003) and A Anghie, Imperialism, Sovereignty and the Making of International Law (Cambridge, Cambridge University Press, 2005). For very insightful engagements with the different approaches and challenges to a TWAIL position, see R Buchanan, 'Writing Resistance Into International Law' (2008) 10 International Community Law Review 1 and OC Okafor, 'Critical Third World Approaches to International Law (TWAIL): Theory, Methodology, or Both?' (2008) 10 International Community Law Review 371; JT Gathii, 'TWAIL: A Brief History of its Origins, its Decentralized Network, and a Tentative Bibliography’ (2011) III:1 Trade, Law and Development 26.

${ }^{110}$ See the brilliant studies by Pahuja, Decolonising International Law (n 12), and Rajah, Authoritarian Rule of Law (n 77), on the ways in which the semantic 'construction' of a field serves to immunise positions of power sustained by a discursive rationality from contestation.

${ }^{111}$ See R Teitel, Transitional Justice (Oxford, Oxford University Press, 2000), and R Nagy, 'Transitional Justice as Global Project: Critical Reflections' (2008) 29 Third World Quarterly 275.

${ }^{112}$ B de Sousa Santos, Toward a New Legal Common Sense: Law, Globalization, and Emancipation (Cambridge, Cambridge University Press, 2002); J Comaroff and JL Comaroff, Theory from the South: Or, How Euro-America Is Evolving Toward Africa (Boulder, Paradigm Publishers, 2012); C Rodríguez-Garavito, 'Ethnicity.gov: Global Governance, Indigenous Peoples, and the Right to Prior Consultation in Social Minefields' (2010) 18 Indiana 
competing vocabularies to address questions of legal and political 'reform', institutional development, 'market' building and 'security' is illustrative of the multiple layers of meaning, historical experiences, associations and connotations, on which each 'new' assertion of political prudence must be seen to rest. Productively inspired by the early frustration vis-à-vis the failed attempts to make available a set of tested legal theories to the legal-political challenges in a development context, ${ }^{113}$ the task today seems to be similar, yet amplified. Not only has the design of a regulatory framework that would arguably befit a progressive political agenda become much more elusive, given the troubled and ironic reversal of post-Welfare State liberal legal theory into neo-liberal functionalism, ${ }^{114}$ but also the reference field for the construction of such a framework has become decisively more differentiated and complex. While it is still true, that a concept such as the 'rule of law' can and should, particularly in the context of development, be understood as a platform for contestation and critical engagement with competing viewpoints and interests, ${ }^{115}$ we are today seemingly asked to reflect on even more aspects of the Rule of Law (RoL) model than before. ${ }^{116}$ Despite the legacy of hundreds of RoL programs developed and pursued under the auspices of the World Bank, the form and content of the RoL is today more contested than ever. ${ }^{117}$ Such contestation is both sobering and significant, especially in a context of intensifying transnational thought exchange regarding the meaning and structure of the RoL. ${ }^{118}$

What seems to emerge from this complexification and intensification of discourses, both of which are driven by a growing interdisciplinary engagement with and contestation of the categories and vocabularies which are being employed, are elements of a transnational discourse that can only inadequately and incompletely be captured under thematic formulas such as 'global governance', 'global constitutionalism' or 'regulatory capitalism'. Indeed, today's investigations into the form(s) and the role of law in development contexts cannot be confined to a space designated as 'law and development'. It is important to highlight the semantic and symbolic baggage that each one is bound to carry from 'domestic' regulatory experiences into the development arena. Neither form of baggage is easily or even adequately captured by a political connotation of 'right' or 'left'. This much the complex regulatory experiences over the last decades have shown.

The question then becomes: where can a 'political' legal theory become attached, if the 'shift from government to governance', greatly amplified by the emergence of a transnational legal pluralist landscape, confronts us with the unavailability of distinct 'centres' of political decision? Without such centres of decision-making, predictable patterns of norm implementation and adjudication and legitimate processes of political participation, is there a focus for a

Journal of Global Legal Studies 1, esp. 13-14 (with reference to J Comaroff and JL Comaroff, Ethnicity Inc.

(Chicago, University of Chicago Press, 2009).

${ }^{113}$ DM Trubek and M Galanter, 'Scholars in Self-Estrangement' (n 8).

${ }^{114}$ P Zumbansen, 'Law After the Welfare State: Formalism, Functionalism and the Ironic Turn of Reflexive Law' (2008) 56 American Journal of Comparative Law 769.

${ }^{115}$ D Kennedy, 'Laws and Development' in J Hatchard and A Perry-Kessaris (eds), Law and Development: Facing Complexity in the 21st Century (London, Cavendish Publishing Limited, 2003).

${ }^{116}$ For series of insightful engagements, see still AC Hutchinson and P Monahan (eds), The Rule of Law: Ideal or Ideology (Toronto, University of Toronto Press, 1987).

${ }^{117}$ Compare, for example, Santos, (n 104), with B Kingsbury, 'The Concept of "Law" in Global Administrative Law' (2009) 20 European Journal of International Law 23.

${ }^{118}$ AN Licht, C Goldschmidt and SH Schwartz, 'Culture Rules: The Foundations of the Rule of Law and Other Norms of Governance' (2007) 35 Journal of Comparative Economics 659; Rajah, Authoritarian Rule of Law (n 79), 37. 
'political' legal theory or does the framing of such a question regress us to a past of spatial, jurisdictional thinking? Such questions are arguably situated further on the normative scale than on the descriptive, sociological one. To be sure, the descriptive, sociological scale has come to such prominence in the global governance discourses of recent years but the normative scale is increasingly difficult to avoid. In light of ever more differentiated accounts of transnational rulemaking and networked interaction, ${ }^{119}$ the pressing nature of 'constitutional' questions investigating the seemingly elusive basis of transnational, post-national legitimacy becomes ever more apparent. ${ }^{120}$ Exploring further concepts of global pluralism ${ }^{121}$ or cosmopolitanism $^{122}$ promises to bring important insights into the concrete interaction between different vertical layers of governance and adjudicatory bodies as well as between horizontally interacting organisations on the international level. But, here too, the problem remains of how to convincingly bring together a sociologically informed account of transnational governance with the political philosophical anxieties, which have for so long been inspiring international thinkers. ${ }^{123}$ On the other hand, engagements with the problem of legitimacy on the basis of a systems theory model of 'world society', which is characterised by functional differentiation and a seemingly irresolvable fragmentation of competing rationalities of 'meaning', ${ }^{124}$ also illustrate how the quest for the 'political' remains as elusive as it is being perceived as urgent. ${ }^{125}$ Simple recipes being unavailable, the task appears to be to get back into the midst of it. David Trubek's work is a great motivator in that regard. Never confining himself to an ivory tower, his scholarship always carries the mark of a political thinker, drawing on an impressive range of theoretical work, never for its own sake, but to lay bare the shortcomings of simplifying accounts and of parochial thinking. Just as he would confront the tensions between a self-forgotten development mandate 'out there' and continuing efforts to build an inclusive justice system domestically, he would likely raise his eyebrows at the mind-numbing depiction of the stakes in Munich's recent airport expansion referendum. Can someone really be that naïve, he might ask. With him, we are awaiting an answer.

\footnotetext{
${ }^{119}$ A Héritier and D Lehmkuhl, 'The Shadow of Hierarchy and New Modes of Governance' (2008) 28 Journal of Public Policy 1; KW Abbott and D Snidal, 'Strengthening International Regulation Through Transnational New Governance: Overcoming the Orchestration Deficit' (2009) 42 Vanderbilt Journal of Transnational Law 501. ${ }^{120}$ A Stone Sweet, 'Constitutionalism, Legal Pluralism, and International Regimes' (2009) 16 Indiana Journal of Global Legal Studies 621; N Walker, 'Taking Constitutionalism Beyond the State' (2008) 56 Political Studies 519; W Mattli and N Woods, 'In Whose Benefit? Explaining Regulatory Change in Global Politics' in W Mattli and N Woods (eds), The Politics of Global Regulation (Cambridge, Cambridge University Press, 2009).

${ }^{121}$ Krisch, Beyond Constitutionalism (n 75).

${ }^{122}$ M Kumm, 'The Cosmopolitan Turn in Constitutionalism: On the Relationship between Constitutionalism in and beyond the State' in JL Dunoff and JP Trachtman (eds), Ruling the World? Constitutionalism, International Law, and Global Governance (Cambridge, Cambridge University Press, 2009).

${ }^{123}$ I Kant, To Perpetual Peace: A Philosophical Sketch (first published 1795, T Humphrey tr, Indianapolis, Hackett, 2003); see also the opening observations in Capps and Machin (n 94), with reference to George Scelle.

${ }^{124}$ N Luhmann, 'Globalization or World Society: How to Conceive of Modern Society?' (1997) 7 International Review of Sociology 67; A Fischer-Lescano and G Teubner, 'Regime-Collisions: The Vain Search for Legal Unity in the Fragmentation of Global Law' (2004) 25 Michigan Journal of International Law 999.

${ }^{125} \mathrm{G}$ Teubner, Verfassungsfragmente: Gesellschaftlicher Konstitutionalismus in der Globalisierung (Berlin, Suhrkamp, 2012), 49-55, 175-188; for a shorter account of this position, see G Teubner, 'Fragmented Foundations: Societal Constitutionalism beyond the Nation State' in P Dobner and M Loughlin (eds), The Twilight of Constitutionalism? (Cambridge, Cambridge University Press, 2010) 327.
} 